\title{
噴流噴霧火炎挙動に及ぼす輻射の影響*
}

$\begin{array}{llllll}\text { 渡 邊 裕 } \text { 章*1,*2, 馬 場 雄 也 }^{* 1} \\ \text { 黒瀬 良 一*2, } & \text { 小 森 } & \text { 悟*2 }\end{array}$

\section{Effect of Radiation on a Spray Jet Flame}

\author{
Hiroaki WATANABE*3, Yuya BABA, \\ Ryoichi KUROSE and Satoru KOMORI

\footnotetext{
${ }^{* 3}$ Energy Engineering Research Laboratory, Central Research Institute of Electric Power Industry (CRIEPI), 2-6-1 Nagasaka, Yokosuka-shi, Kanagawa, 240-0196 Japan
}

\begin{abstract}
Two-dimensional direct numerical simulations (DNS) with and without a radiation model are applied to a spray jet flame, and the effect of the radiation on the spray flame behavior is studied in detail. $\mathrm{N}$-decane $\left(\mathrm{C}_{10} \mathrm{H}_{22}\right)$ is used as a liquid spray fuel, and the droplet motion is calculated by the Lagrangian method. As the combustion reaction model, Arrhenius formulation (ARRS) and enthalpy-based flamelet/progress-variable approach (FPVA-E) for a one-step global reaction are employed. Radiation is taken into account using the discrete ordinate method. The validity of the FPVA-E coupled with the radiation model is assessed by comparing with the reference solution obtained by the ARRS with the radiation model. The results by the ARRS with the radiation model show that the radiation acts to enhance the thermal diffusion and greatly affects the spray flame structure. The effect of the radiation on the spray jet flame can be well captured by the FPVA-E coupled with the radiation model.
\end{abstract}

Key Words : Numerical Simulation, Spray Combustion, Flamelet Model, Thermal Radiation, Jet

\section{1. 緒 言}

噴霧火炎中では，液体燃料の微粒化，油滴の気相へ の分散，蒸発，燃料蒸気の空気との混合反応といった 多くの過程が同時に進行しながら起こるため, その火 炎構造は極めて複雑であり，依然不明な点が多い。こ れまで著者らは，層流対向流中に形成される噴霧火炎 の 2 次元直接数值計算 $(\mathrm{DNS})$ を実施し, 油滴の群燃 焼，火炎片の挙動，および輻射の影響について詳細な 検討を行ってきた ${ }^{(1)(2)(3)(4)}$. 渡邊ら ${ }^{(4)}$ は，対向流場に形 成される噴霧火炎に対して輻射の影響を考慮したDNS を実施することにより，輻射は熱を拡散させ，火炎温 度掞よびすすの生成量を低下させる働きがあることを 明らかにした。しかし，油滴粒子の分散挙動が対向流 火炎とは大きく異なる噴流噴霧火炎に対する影響につ いては明らかにされていない。

一方, 近年では, 燃焼流の large-eddy simulation (LES) に用いられる燃焼モデルとして flamelet モデル が注目されているが，その計算では，輻射は計算負荷 が高いために無視されるか, 簡易的に扱われることが

* 原稿受付 2008 年 1 月 18 日.

*1 正員, (財) 電力中央研究所エネルギー技術研究所 (焉 2400196 横須賀市長坂 2-6-1).

*2 正員, 京都大学大学院工学研究科(画606-8501 京都市左京 区吉田本町).

E-mail: whiroaki@criepi.denken.or.jp
多い. Pitsch \& Steiner ${ }^{(5)}$ は, メタン噴流ガス火炎に対 して flamelet モデルに基づくLES を適用したが，輻射 の影響は optically thin approximation(OTA $)^{(6)} に よ り$ 簡 易化している．他方，噴霧燃焼に関しては，LESによ る検討そのものがほとんどない(1)(7)。これは，噴霧燃 焼に対する燃燒モデルが確立されていないことに加え， 上述の OTA では気相一分散液相間の輻射伝熱を考慮で きないことにも起因する.ごく最近，馬場・黒瀬 ${ }^{(8)(9)}$ は， 噴霧然焼には, 定常 flamelet モデル ${ }^{(10)}$ や反応進行変数 $(C)$ として生成物濃度 $(P)$ を用いる Pierce \& Moin ${ }^{(11)}$ の flamelet/progress-variable 法 (FPVA-P) に比べて, $C$ としてエンタルピ $(h)$ を用いる改良 flamelet/progressvariable 法 (FPVA-E) が油滴の蒸発にともなう潜熱の 気相一分散液相間移動を考慮可能なため, 精度上優れ ていることを明らかにした。しかし，彼らは輻射の影 響を検討するまでには至っていない.

本研究では，噴流噴霧火炎に 2 次元 DNS を適用す ることにより，噴流噴霧火炎挙動に及ぼす輻射の影響 を明らかにするとともに，輻射を考慮した flamelet モ デルの噴霧燃焼場への適用性について検討を行う。な お，ここでの DNS とは流机の支配方程式を乱流モデ ルを用いずに解くことを意味し，燃焼反応モデルを制 約するものではない. 


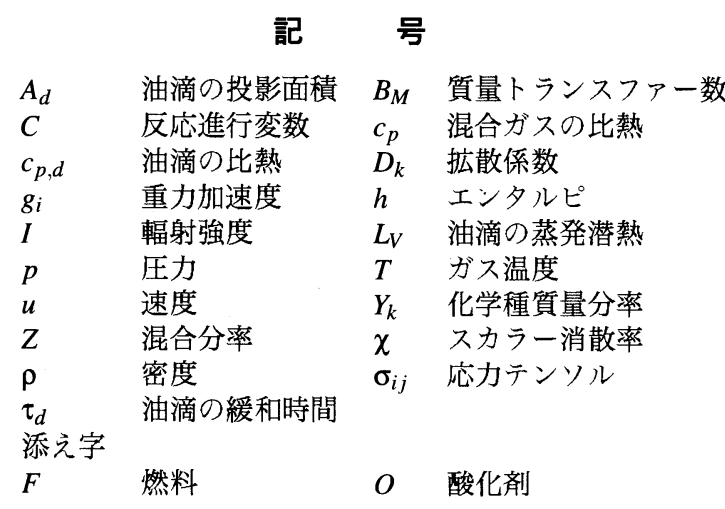

\section{2. 鼓算 方 法}

燃料は $n$-デカシ $\left(\mathrm{C}_{10} \mathrm{H}_{22}\right)$ とし, 燃焼反応には次の 一段総括反応を用いる ${ }^{(12)}$.

$$
\mathrm{C}_{10} \mathrm{H}_{22}+\frac{31}{2} \mathrm{O}_{2} \rightarrow 10 \mathrm{CO}_{2}+11 \mathrm{H}_{2} \mathrm{O}
$$

この反応に対する燃焼モデルとして Arrhenius 式を 採用し，噴霧燃焼場に対する輻射の影響を検討する。 Arrhenius 式による計算では, 次の反応速度式によっ て燃料蒸気の反応速度 $\left(\dot{m}_{F}\right)$ を算出する。

$$
\frac{\dot{m}_{F}}{W_{F}}=A T^{n}\left(\frac{\rho Y_{F}}{W_{F}}\right)^{a}\left(\frac{\rho Y_{O}}{W_{O}}\right)^{b} \exp \left(-\frac{E}{R T}\right)
$$

ここで, $W_{F}$ と $W_{O}$ は，それぞれ燃料と酸化剤の分子 量である. 頻度因子 $A$, 活性化エネルギー $E$, 反応 の次数 $n, a, b$ は，元机ぞれ， $A=3.8 \times 10^{11}, E=$ $1.256 \times 10^{5} \mathrm{~J} / \mathrm{mol}, n=0, a=0.25, b=1.25$ を与える (12). Arrhenius 式は, 最も精度の高い燃焼モデルと考元 られるため，その結果を後述する改良 flamelet/progressvariable 法 (FPVA-E) による計算のリファレンスとする. なお，燃焼モデルの分類については文献六を参照され たい.

2.1 Arrhenius 式による临の支算方程式 Arrhenius 式による計算で考慮する支配方程式は，質量 保存式, 運動量保存式, エネルギー保存式, 抢よび, 化学種保存式である.

$$
\begin{aligned}
& \frac{\partial \rho}{\partial t}+\frac{\partial \rho u_{j}}{\partial x_{j}}=S_{m} \\
& \frac{\partial \rho u_{j}}{\partial t}+\frac{\partial \rho u_{j} u_{i}}{\partial x_{j}}=-\frac{\partial p}{\partial x_{i}}+\frac{\partial \sigma_{i j}}{\partial x_{j}}+S_{u_{i}} \\
& \frac{\partial \rho h}{\partial t}+\frac{\partial \rho u_{j} h}{\partial x_{j}}=\frac{\partial}{\partial x_{j}}\left(\rho a^{*} \frac{\partial h}{\partial x_{j}}\right)+S_{h} \\
& \frac{\partial \rho Y_{k}}{\partial t}+\frac{\partial \rho u_{j} Y_{k}}{\partial x_{j}}=\frac{\partial}{\partial x_{j}}\left(\begin{array}{c}
\rho D_{k} \frac{\partial Y_{k}}{\partial x_{j}} \\
+S_{\text {combu }, k}+S_{Y_{k}}
\end{array}\right.
\end{aligned}
$$

ここで, $Y_{k}$ は $k$ 番目の化学種の質量分率である. 式(5) 中の $a^{*}$ は, $\rho a^{*}=\lambda / c_{p}$ の関係から与える. また, 式 (6) 中の $D_{k}$ は, 全ての化学種に抢いて, $\rho D_{k}=\lambda / c_{p}$ から求める. $S_{m}, S_{u_{i}}, S_{h}$, および $S_{Y_{k}}$ は油滴と気相の 相互作用に関する生成項, また, $S_{c o m b u, k}$ は反応に関 する生成項である(2).

油滴の挙動は, ラグランジェ的に解くことにより求 め, 気相と油滴の相互作用には PSI-Cell 法 ${ }^{(13)}$ を使用す る. 油滴密度は気相よりも十分に大きいと仮定し, 油 滴の挙動に対して抗力と重力の影響のみを考慮する. 流れの剪断力に起因する揚力, 油滴の衝突, 分裂およ び合体は考慮しない(14)(15). 油滴の蒸発モデルには, 非 平衡 Langmuir-Knudsen モデルを用いる ${ }^{(16)(17)}$. 油滴の 位置 $\left(x_{d, i}\right)$, 速度 $\left(u_{d, i}\right)$, 温度 $\left(T_{d}\right)$, および質量 $\left(m_{d}\right)$ に 関する保存式は，次式で表される。

$$
\begin{aligned}
& \frac{d x_{d, i}}{d t}=u_{d, i} \\
& \frac{d u_{d, i}}{d t}=\frac{f_{1}}{\tau_{d}}\left(u_{i}-u_{d, i}\right)+g_{i} \\
& \frac{d T_{d}}{d t}=\frac{\mathrm{Nu}}{3 \operatorname{Pr}}\left(\frac{c_{p}}{c_{p, d}}\right)\left(\frac{f_{2}}{\tau_{d}}\right)\left(T-T_{d}\right) \\
& +\frac{1}{m_{d}}\left(\frac{d m_{d}}{d t}\right) \frac{L_{V}}{c_{p, d}}+\frac{1}{m_{d} c_{p, d}}\left[A_{d} \varepsilon_{d}\left(\pi I-\sigma T_{d}^{4}\right)\right] \\
& \frac{d m_{d}}{d t}=-\frac{\mathrm{Sh}}{3 \mathrm{Sc}} \frac{m_{d}}{\tau_{d}} \ln \left(1+B_{M}\right)
\end{aligned}
$$

ここで, $f_{1}$ と $f_{2}$ はそれぞれ油滴の蒸発による抗力と 熱伝達に関する修正係数である ${ }^{(18)}$. また，式 (9) の右 辺第 2 , 第 3 項は，それぞれ蒸発潜熱抢よび輻射の効 果を与える項である。 $。$ はステファン・ボルツマン定 数 $\left(5.67 \times 10^{-8} \mathrm{~W} /\left(\mathrm{m}^{2} \mathrm{~K}^{4}\right)\right), \varepsilon_{d}$ は粒子放射係数 (炭化 水素油滴の放射率 $(=0.4))^{(19)}$ である。 また， $I$ は輻射

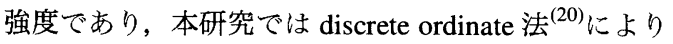
求める. ある方向 $\Omega$ に打忊る位置 $r$ に対する $I$ の輸送 式は，次式で表される。

$$
\Omega \cdot \nabla I(r, \Omega)=-(\alpha+\kappa) I(r, \Omega)+\alpha I_{b}(r)
$$

ここで， $I_{b}$ は各位置における黒体輻射強度， $\alpha$ と $\mathrm{\kappa}$ は， 各化学種の濃度と分圧から決まるガス吸收係数 ${ }^{(21)}$ 粒 子数密度から決まる散乱係数 ${ }^{(22)}$ であり, それぞれ輻射 強度に対するガスと粒子による吸収の効果を表す。各 セルからの輻射強度の輸送方向は, $S_{8}$ 近似によって決 める. なお, inscattering 項は無視する. 式(5)の生成 項 $S_{h}$ に抢ける輻射の効果は, 次式によって考慮する.

$$
\begin{aligned}
S_{h}=-\frac{1}{\Delta V} \sum_{N}\left(Q_{d}\right. & +\frac{d m_{d}}{d t} h_{V, s f} \\
& \left.+\frac{1}{2} \frac{d m_{d}}{d t} v_{i} v_{i}+Q_{r a d}\right)
\end{aligned}
$$




$$
-Q_{\text {rad }}=\alpha\left(\int_{4 \pi} I d \Omega-4 \sigma T^{4}\right)
$$

ここで， $Q_{d}$ および $Q_{\text {rad }}$ は対流および輻射による寄与 項, $h_{V, s f}$ は粒子表面における燃料蒸気のエンタルピで ある。

以上の支配方程式および計算手法の詳細については, 文献 ${ }^{(2)(3)(4)}$ を参照されたい.

\section{2 改良 flamelet/progress-variable 法 (FPVA-}

E) Pierce \& Moin ${ }^{(11)} の$ flamelet/progress-variable 法 (FPVA-P) では，データベースである flamelet ライブラ リ (chemtable) を参照しながら変動流れ場を計算する ことで燃焼流に対する解を得る.変動流れ場について は, 質量保存式 (式 (3)) と運動量保存式 (式 (4)) に加 え, 次の混合分率 $(Z)$, および反応進行変数 $(C)$ の保 存式を解く.

$$
\begin{aligned}
& \frac{\partial \rho Z}{\partial t}+\frac{\partial \rho u_{j} Z}{\partial x_{j}}=\frac{\partial}{\partial x_{j}}\left(\rho D_{Z} \frac{\partial Z}{\partial x_{j}}\right)+S_{Z} \\
& \frac{\partial \rho C}{\partial t}+\frac{\partial \rho u_{j} C}{\partial x_{j}}=\frac{\partial}{\partial x_{j}}\left(\rho D_{C} \frac{\partial C}{\partial X_{j}}\right)+S_{C}
\end{aligned}
$$

ここで， $D_{Z}$ および $D_{C}$ は，それぞれ $Z$ および $C$ の Le 数を 1 と仮定し, $\rho D_{Z}=\lambda / c_{p}, \rho D_{C}=\lambda / c_{p}$ により与 える。また， $S_{Z}$ および $S_{C}$ は， $Z$ および $C$ の燃料液滴 の蒸発に伴う生成項である. FPVA-Pでは, 変動流れ 場の計算から得られる $Z$ と $C$ を参照パラメータとし て, chemtable から密度 $(\rho)$, ガス温度 $(T)$, および化 学種濃度 $\left(Y_{k}\right)$ を求める。

$$
\rho=\rho(Z, C), \quad T=T(Z, C), \quad Y_{k}=Y_{k}(Z, C)
$$

なお，本研究では輻射の導入およびその影響解明を目 的とし, 式 (1) の一段総括反応を考慮するため利点は あまりないが，数百段に渡る多段反応を考慮する場合 には，本 flamelet 法は有効になる.

文献 ${ }^{(11)}$ では燃焼生成ガスの濃度 $\left(\mathrm{Y}_{\mathrm{H}_{2} \mathrm{O}}+\mathrm{Y}_{\mathrm{CO}_{2}}\right)$ を $\mathrm{C}$ と して与えているが, 必ずしもCをこのように選ぶ必要は

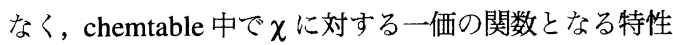
量であればCとして採用することができる．著者ら ${ }^{(8)(9)}$ は，Cにエンタルピ $(h)$ を採用する改良 FPVA(FPVA-E) を提案した。本来, ガス温度は, 輻射や燃料液滴の蒸 発に伴う潜熱移動の影響を受けるため, 従来の flamelet モデルのように火炎片にかかる伸張率のみで決定する ことができない， $h$ を $C$ とする利点は，こうした熱工 ネルギーの増減を $C$ を介して変動流れ場 (物理空間) と chemtable( $Z$ 空間) との間でやりとりできる点にある. このとき, 式(14), および式(15)の生成項はそれぞれ 次式で表され, 結局, 式(15) は式(5)に一致する.

$$
S_{Z}=-\sum_{N} \frac{d m_{d}}{d t}
$$

$$
S_{C}=S_{h}
$$

2.3 叶算条件 図 1 に計算領域と流入条件の概 略を示す。噴霧油滴は, 図 1 のノズルから算術平均粒 径 $d_{10}=50 \mu \mathrm{m}$ (最大 $100 \mu \mathrm{m}$, 最小 $1 \mu \mathrm{m}$ )のものを, 質 量流量 $20 \mathrm{~g} / \mathrm{s}$ となるようランダムに噴射した。噴霧油 滴の流入速度は，ガス流速と同様とした。計算領域は 二次元の $7 \mathrm{~cm} \times 3 \mathrm{~cm}\left(L_{x} \times 2 L_{y}\right)$ の矩形領域であり, 計 算格子は $500 \times 250$ 点を配置した，格子は不等間隔の 直交ス夕ガード格子を使用した。 スパン方向の空間刻 みは反応帯近傍で $\Delta y=50 \mu \mathrm{m}$, 主流方向の空間刻みは 一定で $\Delta x=150 \mu \mathrm{m}$ とした．また，流入境界以外はす ベて自由流出境界とし，輻射に対する周囲境界温度は $300 \mathrm{~K}$ とした.

運動量保存式の移流項には 2 次精度完全保存スキー ム ${ }^{(23)}$, 温度や化学種質量分率などのスカラー量の対 流には QUICK スキーム ${ }^{(24)}$ を用いた。 その他の項に ついては 2 次精度中心差分法を用いた. 計算のアルゴ リズムは fractional step 法 ${ }^{(25)}$ を用い, 時間積分は 2 次 精度 Runge-Kutta 法を用いた。 また，物性についてす べて CHEMKIN ${ }^{(26)(27)}$ に従って算出した。

噴霧燃焼場に対する輻射の影響を調べるため, Arrhenius 式を用い輻射の影響を考慮するケース (ARRS-R) と輻射の影響を無視するケース (ARRS)を 計算する。 また，燃焼モデルにFPVA-Eを用い輻射の 影響を考慮するケース (FPVA-ER) と輻射の影響を無 視するケース (FPVA-E) を計算し, flamelet モデルと 輻射モデルのカップリング計算の有効性を検討する. 表 1 に，本研究において検討するケースをまとめる.

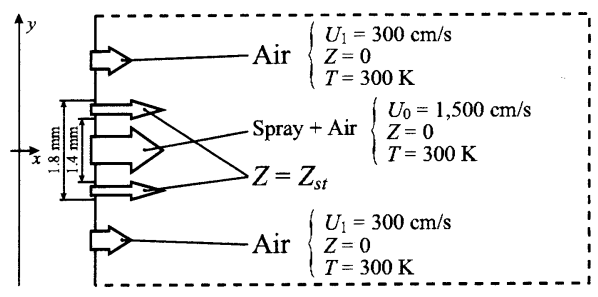

Fig. 1 Schematics of computational setup.

Table 1 Cases presented.

\begin{tabular}{c|c|c}
\hline Cases & Combustion model & Radiation \\
\hline ARRS-R & Arrhenius formation & Yes \\
ARRS & Arrhenius formation & No \\
FPVA-ER & Modified FPVA (FPVA-E) & Yes \\
FPVA-E & Modified FPVA (FPVA-E) & No \\
\hline
\end{tabular}



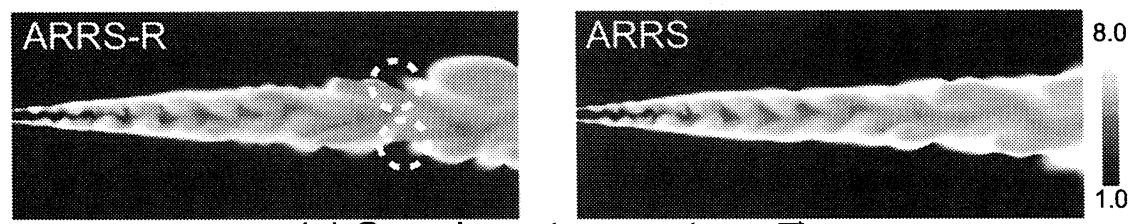

(a) Gas-phase temperature, $T^{*}$
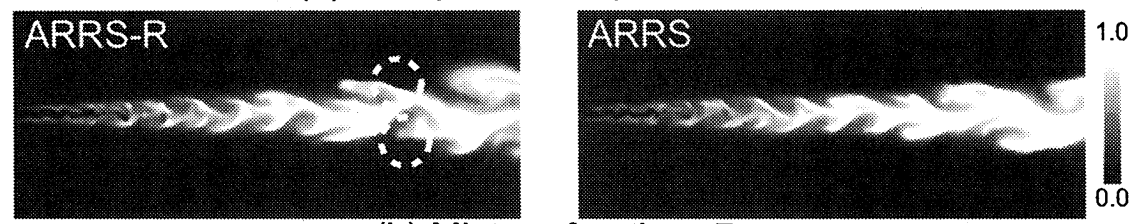

(b) Mixture fraction, $Z$
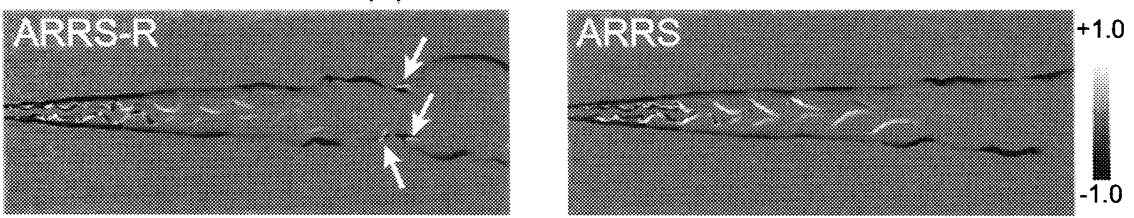

\section{(c) Flame index, $F I$}
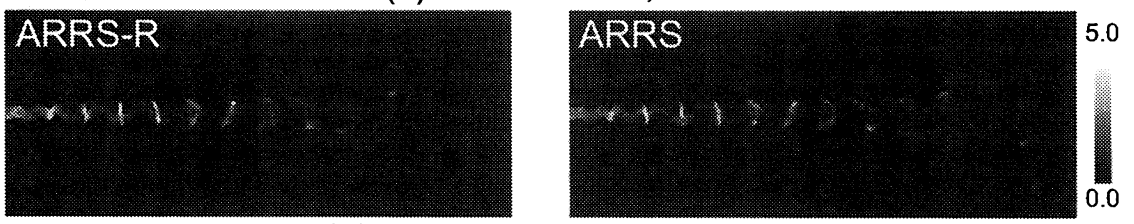

(d) Number of droplets, $N_{p}$

Fig. 2 Comparisons of instantaneous distributions of (a) gas-phase temperature, $T^{*}$, (b) mixture fraction, $Z$, (c) flame index, FI, and (d) number of droplets, $N_{d}$, between ARRS-R and ARRS.

\section{3. 結果および考察}

$3 \cdot 1$ 輻射の影響困 2 に, Arrhenius 式を用いた 輻射あり(ARRS-R) と輻射なし (ARRS) の計算の瞬間 分布を比較する。図 2(a) は，代表温度 (300K) により 無次元化されたガス温度 $\left(T^{*}\right)$ 分布の比較である. 図か ら, ARRS-R と ARRSの双方とも噴流の上下両縁に高 温の領域が形成されているが，この高温領域は輻射を 考慮したARRS-Rの方が狭いことがわかる。これは輻 射の影響により，高温領域の熱が周囲に拡散されるた めであると考えられる。 また，ARRS-Rでは $x^{*}=4.0$ (ただし， $x^{*}$ は $L_{y} / 2$ によって無次元化された值) 付近 において，噴流の上下両縁に高温領域が大きく途切れ る箇所 (図中白破線内), すなわち失火が観察されるが, ARRS ではこうした挙動は見られない.

図 2(b) に, 混合分率 $(Z)$ 分布の比較を示す. 図から, 一見して両者の分布形状に大きな差異は認められない が，図 2(a)のARRS-Rにおいて観察された失火箇所 に注目すると, Zが高い值を示す領域が火炎の外縁に まで達していることがわかる (図中白破線内). ARRS
では Zが高い值を示す領域が火炎の外縁にまで達する 箇所は見られないことから，ARRS-Rにおける失火は， 燃料蒸気が過濃で, $Z$ の勾配, すなわちスカラー消散 率 $\left(\chi=2 D_{Z}|\nabla Z|^{2}\right)$ が大きな場所であると考えられる.

図 2(c) に, flame index $(F I)$ 分布の比較を示す。ただ L, FI は予混合火炎と拡散火炎を判別するパラメー 夕であり，次式で定義される(28).

$$
F I=\nabla Y_{C_{10} H_{22}} \cdot \nabla Y_{O_{2}}
$$

$F I$ は，正であれば予混合火炎を，負であれば拡散火炎 を表す．また，ここに示す FIは，火炎構造のみを抽出 するため, $T^{*}$ が 5.0 以上の領域でのみ表示を行った. 図から，ARRS-R と ARRS には，噴流の上下両緑に おける強い拡散火炎の領域と, 中心軸付近における波 打った予混合火炎の領域が混在していることがわかる. また，予混合火炎は下流で弱まるが，特に ARRS-Rで は，下流側でも予混合火炎が観察される。この予混合 火炎は, 前述の失火箇所から伸びている (図中白矢印). これは, 失火箇所において過濃な燃料蒸気が, 着火す るよりも先に火炎外縁の外側を流れる酸化剂と混合し, 

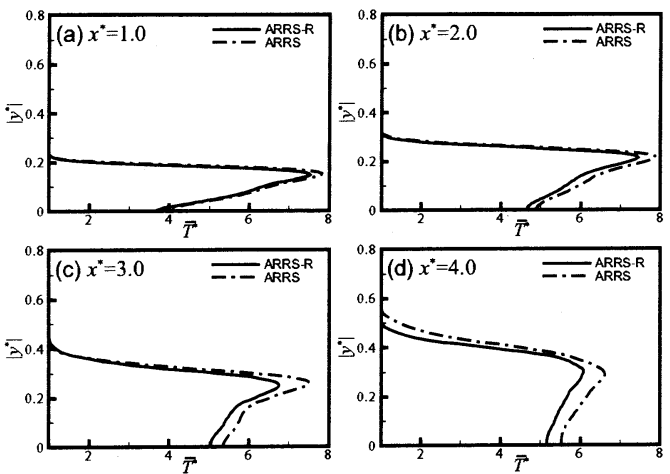

Fig. 3 Comparison of spanwise distributions of timeaveraged gaseous temperature at (a) $x^{*}=1.0$, (b) $x^{*}=2.0$, (c) $x^{*}=3.0$ and (d) $x^{*}=4.0$.
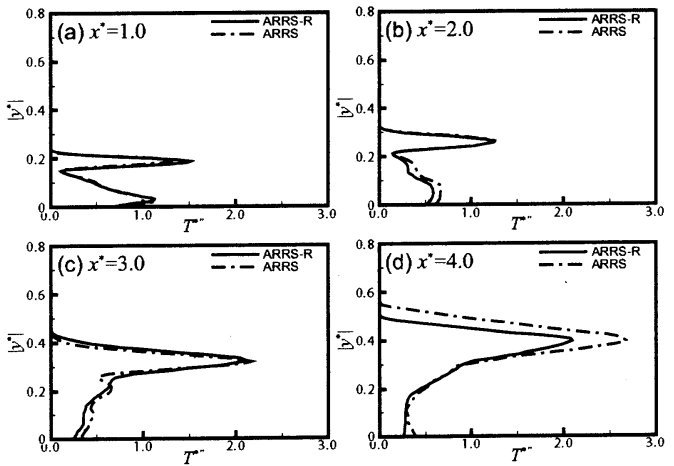

Fig. 4 Comparison of spanwise distributions of r.m.s. of gaseous temperature at (a) $x^{*}=1.0,(\mathrm{~b}) x^{*}=$ 2.0, (c) $x^{*}=3.0$ and $(\mathrm{d}) x^{*}=4.0$.

予混合気を形成するために現れるものと考えられる。

図 2(d) に，粒子数 $\left(N_{d}\right)$ 分布の比較を示す. 図から, $N_{d}$ が高い值を示すのは，図 2(a) との比較から， $T^{*}$ が 比較的低い值を示す場所であることがわかる。しかし ながら，ARRS-R と ARRS との間に顕著な相違は見ら 水ない.

図 3 に, $T^{*}$ のスパン方向時間平均分布 $\left(\bar{T}^{*}\right)$ に対 する ARRS-R と ARRS との比較を示す。ここで，(a) $x^{*}=1.0$, (b) $x^{*}=2.0$, (c) $x^{*}=3.0$, および (d) $x^{*}=4.0$ である，図から，噴流の上流側である $x^{*}=1.0$ では, ARRS-R と ARRS の分布形状に大きな差異は見られな いが， $x^{*}=2.0 \sim 4.0$ と下流側に進むに従って， $T^{*}$ が ピーク值をもつスパン方向位置は変わらないものの, ARRS-R のピーク值は ARRSのそれよりも $T^{*}=0.5$ 〜 0.8 程度小さくなるとともに, 高温領域の幅が減少 することがわかる。これは図 2(a) における議論と同様 に，輻射が熱を周囲に拡散させ，熱損失が発生してい
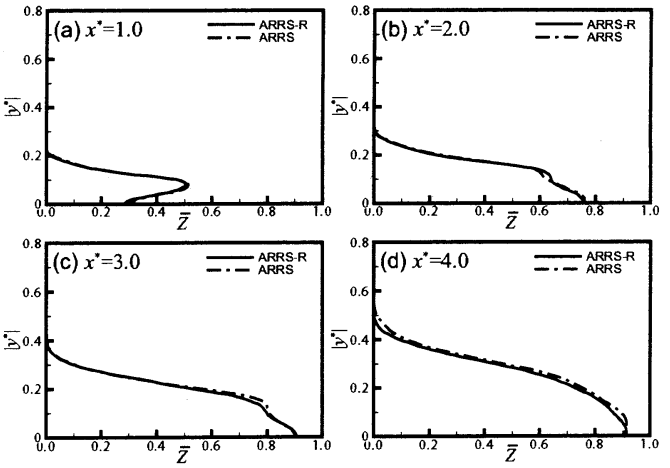

Fig. 5 Comparison of spanwise distributions of timeaveraged mixture fraction at (a) $x^{*}=1.0$, (b) $x^{*}=2.0$, (c) $x^{*}=3.0$ and (d) $x^{*}=4.0$.
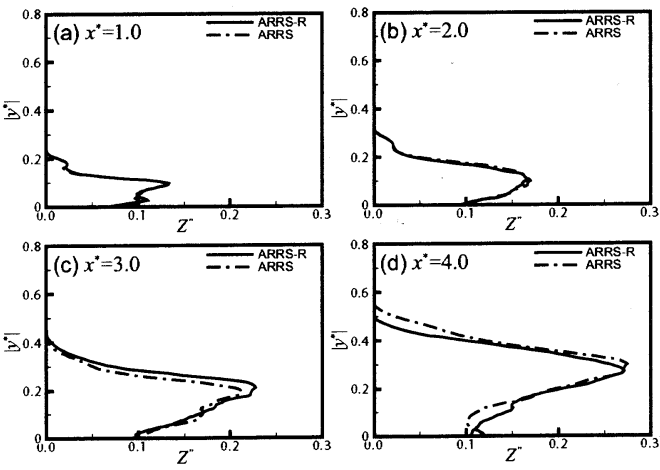

Fig. 6 Comparison of spanwise distributions of r.m.s. of mixture fraction at (a) $x^{*}=1.0,(\mathrm{~b}) x^{*}=2.0$, (c) $x^{*}=3.0$ and $(\mathrm{d}) x^{*}=4.0$.

るためである.

図 4 に, $T^{*}$ のスパン方向 $\mathrm{rms}$ 值分布 $\left(T^{*^{\prime \prime}}\right)$ に対する ARRS-R と ARRS との比較を示す。図から， $T^{*^{\prime \prime}}$ の分 布は, 図 3 と同様に, 上流側の $x^{*}=1.0$ では ARRS-R とARRS との間に大きな差異は見られない.しかし， 下流に進むに従って，ピーク值をもつスパン方向位置 は変わらないものの, ARRS-Rのピーク值は ARRSの それよりも $T^{*^{\prime \prime}}=0.5$ 程度小さくなる。このことから， 輻射が熱を周囲に拡散させる効果は，時間平均温度を 下げると同時に，温度の変動を抑制する傾向にあるこ とがわかる。

図 5 に, $Z$ のスパン方向時間平均分布 $(\bar{Z})$ に対する ARRS-R とARRS の比較を示す。図 3 で見たように, ARRS-R は ARRS に比較して，下流側の $x^{*}=3.0 \sim 4.0$

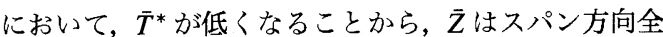
体にわたりわずかに低い値を示すが，分布形状にはほ とんど相違は見られない. 一方，図 6 に示す $Z$ のスパ 

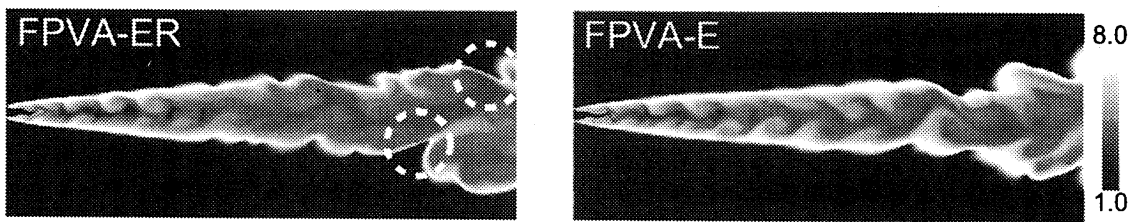

(a) Gas-phase temperature, $T$
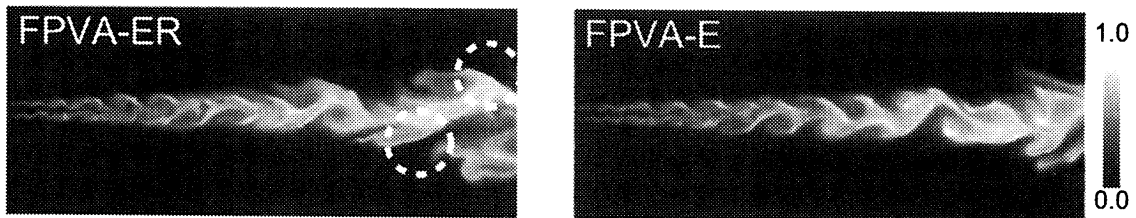

(b) Mixture fraction, $Z$
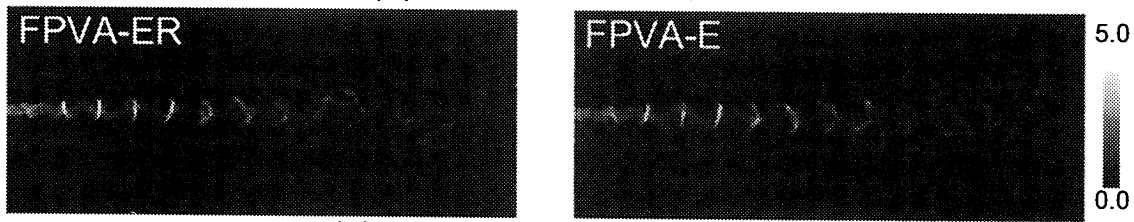

(c) Number of droplets, $N_{p}$

Fig. 7 Comparisons of instantaneous distributions of (a) gas-phase temperature, $T^{*}$, (b) mixture fraction, $Z$, and (c) number of droplets, $N_{d}$, between FPVA-ER and FPVA-E.

ン方向 $\mathrm{rms}$ 值分布 $\left(Z^{\prime \prime}\right)$ では，両者の分布形状に大き

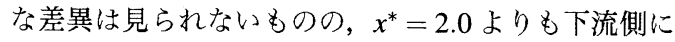
おいて, ARRS-Rのピーク值がARRSのそれよりも若 干低い值を示していることがわかる。

$3 \cdot 2$ 輻射を考慮した改良 flamelet/progressvariable(FPVA-E) 法による計算 図 7 に, FPVA-E を用いた輻射を考慮したケース (FPVA-ER) と輻射を 無視したケース (FPVA-E) の計算の瞬間分布の比較 を示す. 図 7(a)に, ガス温度 $\left(T^{*}\right)$ 分布の比較を示 す.図から, FPVA-ER と FPVA-Eの双方とも噴流の 上下両縁に高温の領域が形成されており，図 2(a)の Arrhenius 式による計算と同様の火炎形状を示してい ることがわかる。また，輻射を考慮した FPVA-ER は，考慮しない FPVA-Eに比べて， $T^{*}$ のピーク值が 低く，その高温領域は狭くなっており， Arrehius 式に よる計算と同様の傾向を観察することができる。し かしながら，ARRS-R に見られたような明確な失火 はFPVA-ER には見られない.

図 7(b) に, 混合分率 $(Z)$ 分布の比較を示す. 図から, FPVA-ER と FPVA-E のZの分布形状に大さな相違は 見られないが, FPVA-ER の噴流外縁の高温領域が薄 い領域において，Zおよび $\chi$ が大きな值を示す傾向が 見られる (図中白波線内).

図 7(c) に，粒子数 $\left(N_{d}\right)$ 分布の比較を示す. 図 2(a) および (c) に見られたように, $N_{d}$ が高い值を示すの
は， $T^{*}$ が比較的低い值を示す場所であることがわか る. $N_{d}$ の分布については, FPVA-ER と FPVA-E との 間に顕著な相違は見られない。

図 8 に， $T^{*}$ のスパン方向時間平均分布 $\left(\bar{T}^{*}\right)$ に対す る FPVA-ER と FPVA-E との比較を示す。なお，比較 のため，図中にはARRS-R と ARRS の結果もあわせ て示す. 図から，FPVA-E 法による計算の $T^{*}$ 分布は, Arrhenius 式による計算のそれよりも，輻射の有無に 寄らず全体的に低い值を示している。これは，拡散燃 焼をべースとしている FPVA-E 法が図 2(c) に見られ るような予混合燃焼の影響を考慮できないことに起因 すると推察される ${ }^{(8)}$. しかしながら，輻射を考慮する ことにより観察された ARRS-R と ARRS との差異は, FPVA-ER と FPVA-Eの結果にも観察することができ る.すなわち，噴流の上流側の $x^{*}=1.0$ では FPVAER と FPVA-E との間に大きな差異は見られないが, $x^{*}=2.0 \sim 4.0$ と下流側に進むに従って, FPVA-ER に おける $T^{*}$ のピーク值は FPVA-Eのそれよりも小さく なるとともに, 高温領域の幅が減少する。このことか ら，輻射を考慮した FPVA-E法は，輻射が時間平均温 度場に及ぼす定性的な影響を考慮することが可能であ ることがわかる。図 9 に, $T^{*}$ のスパン方向 $\mathrm{rms}$ 值分 布 $\left(T^{*^{\prime \prime}}\right)$ に対する FPVA-ER と FPVA-E との比較を示 す. 図から, $T^{*^{\prime \prime}}$ の分布は, 図 8 と同様に, 上流側の $x^{*}=1.0$ では FPVA-ER と FPVA-E との間に大きな差 

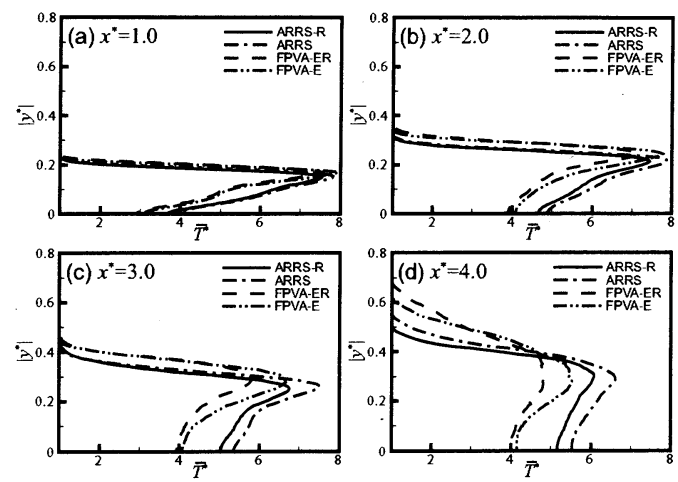

Fig. 8 Comparison of spanwise distributions of timeaveraged gaseous temperature at (a) $x^{*}=1.0$, (b) $x^{*}=2.0$, (c) $x^{*}=3.0$ and (d) $x^{*}=4.0$.
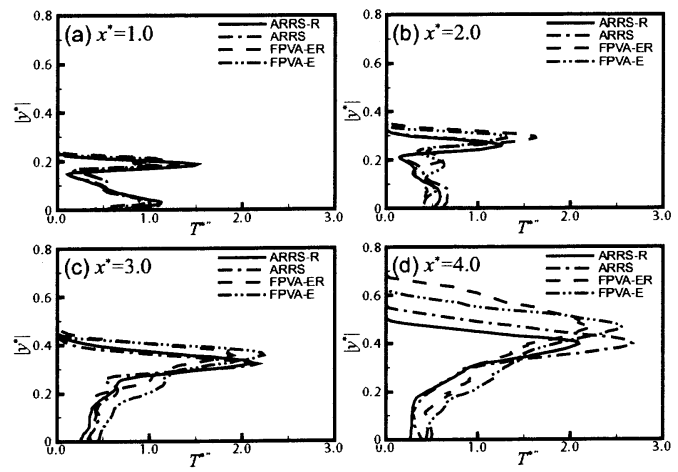

Fig. 9 Comparison of spanwise distributions of r.m.s. of gaseous temperature at (a) $x^{*}=1.0$, (b) $x^{*}=$ $2.0,(\mathrm{c}) x^{*}=3.0$ and $(\mathrm{d}) x^{*}=4.0$.

異は見られないが, 下流側に進むに従って, FPVA-ER のピーク值は FPVA-Eのそれよりも小さくなる。これ についても，ARRS-R とARRS との間に見られる傾向 と同様であり，輻射を考慮した FPVA-E 法 (FPVA-ER) は, 温度の変動場に対する輻射の影響についても定性 的に再現することが可能であることがわかる.

図 10 に, $Z$ のスパン方向時間平均分布 $(\bar{Z})$ に対す る FPVA-ER と FPVA-E との比較を示す。図 8 で見た ように, FPVA-ER は FPVA-E に比較して, 下流側の $x^{*}=3.0 \sim 4.0$ において， $\bar{T}^{*}$ が低くなることから，ス パン方向全体にわたりわずかに低い值を示すが，分布 形状にはほとんど相違は見られない。 なお， $x^{*}=3.0$ $\sim x^{*}=4.0$ において, Arrhenius 式による計算よりも FPVA-E 法によるものの方が低い值を示すのは，前述 したように, 全体的に $T^{*}$ が低いことによるものと思 われる。一方, 図 11 に㧍ける $Z$ のスパン方向時間平 均分布 $\left(Z^{\prime \prime}\right)$ の比較から, $Z$ のスパン方向 $\mathrm{rms}$ 值分布
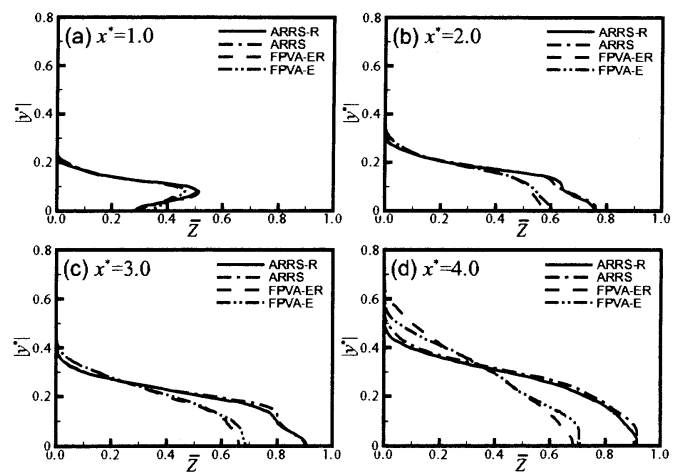

Fig. 10 Comparison of spanwise distributions of timeaveraged mixture fraction at (a) $x^{*}=1.0$, (b) $x^{*}=2.0,(\mathrm{c}) x^{*}=3.0$ and (d) $x^{*}=4.0$.
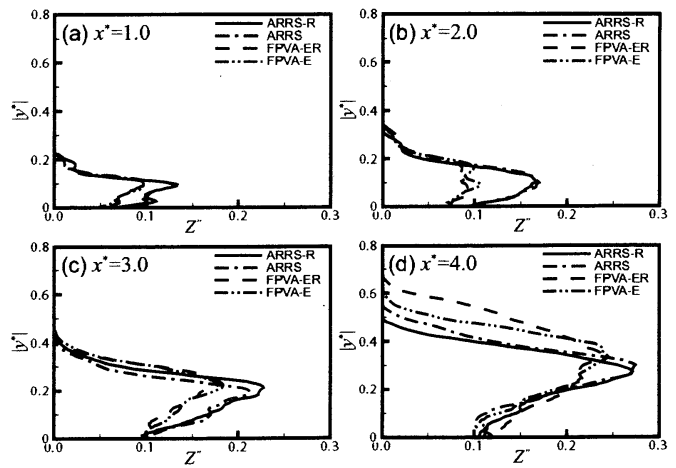

Fig. 11 Comparison of spanwise distributions of r.m.s. of mixture fraction at (a) $x^{*}=1.0,(\mathrm{~b}) x^{*}=2.0$, (c) $x^{*}=3.0$ and $(\mathrm{d}) x^{*}=4.0$.

$\left(Z^{\prime \prime}\right)$ では，両者の分布形状に大きな差異は見られない ものの， $x^{*}=2.0$ よりも下流側において，ARRS-Rの ピーク值が ARRSのそれよりもわずかに低い值を示 すことがわかる。こうした傾向はいずれも，Arrhenius 式による計算において観察された, 輻射が $Z$ の挙動に 及ぼす影響とほぼ一致している。

\section{4. 結 論}

本研究では, $n$-デカンを燃料とした 2 次元噴流噴霧 火炎の DNS を実施することにより, 噴流噴霧火炎挙 動に及ぼす輻射の影響と，その火炎への flamelet モデ ルの適用性について検討を行った. 得られた主な知見 は，以下の通りであった。

1. 輻射は, 噴流噴霧火炎の燃焼挙動に大さな影響を 及ぼす，輻射を考慮した場合に比べて，輻射を考 慮しない場合のガス温度や混合分率の時間平均值 と $\mathrm{rms}$ 值のピーク值はともに過大評価される.こ 
れは，輻射が熱を拡散させる効果をもつことに起 因する.この結果は, 噴流噴霧火炎の燃焼挙動を 正確に予測するためには, 輻射の影響を考慮する ことが不可欠であることを示している.

2. エンタルピを反応進行変数 $C$ に用いる改良 flamelet/progress-variable(FPVA-E) 法と輻射モデ ルとカップリングした本手法は，噴流噴霧火炎 の燃焼挙動に及ぼす輻射の影響を比較的良好に捉 えることができる。

\section{謝辞}

本研究の一部はゼネラル石油研究奨励財団の援助を 受けて行われた。ここに記して，謝意を表する。

\section{文献}

(1) Kurose, R., Desjardins, O., Nakamura, M., Akamatsu, F. and Pitsch, H., Numerical simulation of spray flames, CTR Annual Research Briefs-2004, Center for Turbulence Research, NASA Ames/Stanford Univ. (2004), 269-280.

(2) Nakamura, M., Akamatsu, F., Kurose, R. and Katsuki, M., Combustion mechanism of liquid fuel spray entering gaseous flame front, Phys. Fluids, 17 (2005), 123301.

(3) Watanabe, H., Kurose, R., Hwang, S.-M. and Akamatsu, F., Characteristics of flamelet in spray flames formed in a laminar counterflow, Combust. Flame, 148 (2007), 234248.

(4) Watanabe, H., Kurose, R., Komori, S. and Pitsch, H., Effects of radiation on spray flame characteristics and soot formation, Combust. Flame, 152 (2008), 2-13.

(5) Pitsch, H. and Steiner, H., Large-eddy simulation of a turbulent piloted methane/air diffusion flame (Sandia flame D), Phys. Fluids, 12 (2000), 2541-2554.

(6) Barlow, R. S., Karpetis, A. N., Frank, J. H. and Chen, J.Y., Scalar profiles and NO formation in laminar opposedflow partially premixed methane/air flames, Combust. Flame, 127 (2001), 2102-2118.

(7) Kurose, R., Large-eddy simulation of turbulent combustion -Application to spray combustion -, J. GTSJ, 35 (2007), 243-252.

(8) Baba, Y. and Kurose R., Flamelet/progress-variable approach on numerical simulation of spray combustion, Trans. JSME Ser. B, 73-727 (2007), 863-870.

(9) Baba, Y. and Kurose R., Analysis and flamelet modeling for spray combustion, J. Fluid Mech., submitted.

(10) Peters, N., Laminar diffusion flamelet models in nonpremixed turbulent combustion, Prog. Energy Combust. Sci., 10 (1984), 319-339.

(11) Pierce, C. D. and Moin, P., Progress-variable approach for large-eddy simulation of non-premixed turbulent combustion, J. Fluid Mech., 504 (2004), 73-94.

(12) Westbrook, C. K. and Dryer, F. L., Chemical kinetic modeling of hydrocarbon combustion, Prog. Energy, Combust. Sci., 10 (1984), 1-57.
(13) Crowe, C. T., Sharma, M. P. and Stock, D. E., The Particle-Source-In Cell (PSI-CELL) model for gas-droplet flows, Trans. ASME, J. of Fluids Eng., 99 (1977), 325-332.

(14) Kurose, R. and Komori, S., Drag and lift forces on a rotating sphere in a linear shear flow, J. Fluid Mech., 384 (1999), 183-206.

(15) Ham, F., Apte, S. V., Iaccarino, G., Wu, X., Herrmann, M., Constantinescu, G., Mahesh, K. and Moin, P., Unstructured LES of reacting multiphase flows in realistic gas turbine combustors, CTR Annual Research Brief-2003, Center for Turbulence Research, NASA Ames/Stanford Univ. (2003), 139-159.

(16) Miller, R. S., Harstad, K and Bellan, J., Evaluation of equilibrium and non-equilibrium evaporation models for many-droplet gas-liquid flow simulations, J. Multiphase Flow, 24 (1998), 1025-1055.

(17) Miller, R. S. and Bellan, J., Direct numerical simulation of a confined three-dimensional gas mixing layer with one evaporating hydrocarbon-droplet-laden stream, J. Fluid Mech., 384 (1999), 293-338.

(18) Kurose, R., Makino, H., Komori, S., Nakamura, M., Akamatsu, F. and Katsuki, M., Effects of outflow from the surface of a sphere on drag, shear lift, and scalar diffusion, Phys. Fluids, 15 (2003), 2338-2351.

(19) Tseng, C. C. and Viskanta, R., Effect of radiation absorption on fuel droplet evaporation, Combust. Sci. and Tech., 177 (2005), 1511-1542.

(20) Fiveland, W. A., Three-dimensional radiative heattransfer solutions by the discrete-ordinates method, $J$. Thermophysics, 2 (1988), 309-316.

(21) Grosshandler, W. L., A narrow-band model for radiation calculation in a combustion environment, NIST Technical Note, 1402 (1993).

(22) Modest, M. F., Radiative heat transfer, McGraw-Hill, Inc., (1993).

(23) Morinishi, Y., Lund, T. S., Vasilyev, O. V. and Moin, P., Fully conservative higher order finite difference schemes for incompressible flow, J. Compu. Phys., 143 (1998), 90124.

(24) Leonard, A., A stable and accurate convective modelling procedure based on quadratic upstream interpolation, Compu. Meth. Appl. Mech. Eng., 19 (1979), 59-98.

(25) Kim, J. and Moin, P., Application of a fractional step method to incompressible Navier-Stokes equations, $J$. Compu. Phys., 59 (1985), 308-323.

(26) Kee, R. J., A fortran computer code package for evaluation of gas-phase multi-component transport properties, Sandia report, (1986), SAND86-8246.

(27) Kee, R. J., A fortran chemical kinetics package for the analysis of gas phase chemical kinetics, Sandia report, (1989), SAND89-8009B.

(28) Yamashita, H., Shimada, M. and Takeno, T., A numerical study on flame stability at transition point of jet diffusion flames, Proc. Twenty-fifth Symp. (Int.) on Combust., The Combustion Institute, (1996), 27-34. 